$\mathbf{4 4}: 42$

第 48 回日本老年医学会学術集会記録

〈シンポジウム III：専門領域における老年医学〉

\title{
1. 日本高齢消化器医学会議
}

大野 眞朋 水野 弥一 河出昌也 林 嘉光

Key words : 経皮内視鏡的胃瘻造設術 $(\mathrm{PEG})$, 合併症, カテーテル交換

（日老医誌 $2007 ； 44 ： 42-45 ）$

\section{はじめに}

近年, 嚥下障害を持つ高齢の方々への経腸栄養法とし て，経皮内視鏡的胃瘦造設術 (Percutaneous Endoscopic Gastrostomy, 以下 PEG) が広く行われている1). 日本 高齢消化器医学会議においても PEGに関連した演題が 多く見られ，多岐にわたる検討がなされている2).

現在 PEG の患者数は 20 万人を超えた. その一方で残 念ながら PEGの造設および交換時における合併症が少 なからず存在している. 今回, こうした合併症の検討を 通じて, 今後合併症をできる限り無くしていく対処法に ついて考えたい.

\section{PEG 造設時の合併症}

PEG の合併症の検討は名古屋市厚生院および名古屋 市立大学関連病院 4 施設の協力を得て行った．検討期間 は 2002 年 5 月から 2005 年 12 月までの 3 年 8 力月であ る.

集計した PEG 症例は 171 例であった. 患者背景は男 : 女が $78: 93$ と女性の方が多く, 年歯は 56 歳から 98 歳, 平均年歯令は 82.1 歳であった。基礎疾患としては脳梗塞 後遺症 87 例, 脳出血後遺症 27 例, くも膜下出血後遺症 6 例と脳血管障害後遺症が 7 割以上を占めていた。集計 の結果, 術前検查は 171 例中上部消化管内視鏡検査が 79 例 $(46 \%)$ ，腹部 CT 検査が 17 例 $(10 \%)$ の症例で行わ れていた，術中の胃壁固定は 60 例 $(35 \%)$ の症例で行 われていた。これを最近 1 年に限ると $80 \%$ 以上の症例 で行われており，胃壁固定の有用性に対する認識が高 まっていると考えられた ${ }^{3) \sim 5)}$. PEGの手技の種類は, pull

From Japanese conference of geriatric gastroenterology Naotomo Ono, Yaichi Mizuno, Masaya Kawade, Yoshimitsu Hayashi：日本高齢消化器医学会議
法が $65 \%$, push 法 13\%, イントロデューサー法が $22 \%$ であった。

合併症は 171 例中 12 例 $(7 \%)$ に認められた。この中 には PEG 後 2 週間で死亡された関連死が 1 例あった. 造設時合併症の内訳は, 創感染, 出血が各 3 例, 以下胃 粘膜下血腫, 胃穿孔, 敗血症, バンパー埋没症候群など であった，創感染に関しては，チューブが口腔を経由す る方法で感染が起こりやすいとの報告 ${ }^{677)}$ と一致し, pull 法で 2 例, push 法で 1 例認められた. イントロデュー サー法では創感染は見られなかった。出血は 3 例に認め られたが, 全て初期の圧迫などの保存的療法で止血し, 輸血や止血剤投与を要するまでの重篤な出血はなかっ た.

PEG 後尿路感染症からの敗血症による関連死と考え られる症例を経験した。嚥下障害のある 86 歳男性で, 繰り返す誤嬩性肺炎のため予定された PEG が何度も延 期されていた. しかし家族の強い希望があり, 抗生物質 の投与により, 解熱をみたところで, PEG を行った. PEG 後 7 日目頃より血尿, 発熱, 血小板の減少が出現した. 尿路感染からの敗血症および DIC と診断し, 諸治療を 行ったが 14 日目に死亡した．剖検所見では腎髄質の尿 細管内に膿の貯留があり, PAS 染色組織像で, 微小膿 瘍内にカンジダの感染を多数認めた. 系球体毛細血管内 にはフィブリン析出を伴う血栓の形成が認められ, DIC の所見であった，術後 2 週間にもかかわらず，肉眼的に 胃瘻壁は全く形成されておらず，胃壁固定部分において も壁側腹膜と胃漿膜との癒着はみられなかった．組織で は真皮から皮下筋層, 腹膜面までにいたる広範囲の壊死 を認めた（図 1)。胃瘻形成が不完全であったのは，敗 血症により全身状態が悪化し肉芽形成が不良となったた めと考えられた．造設後の㾞孔形成は生体側の状態に左 右される要素が多分に存在することが示唆された. PEG の術前評価は十分慎重に行い, 全身状態が不安定な時期 

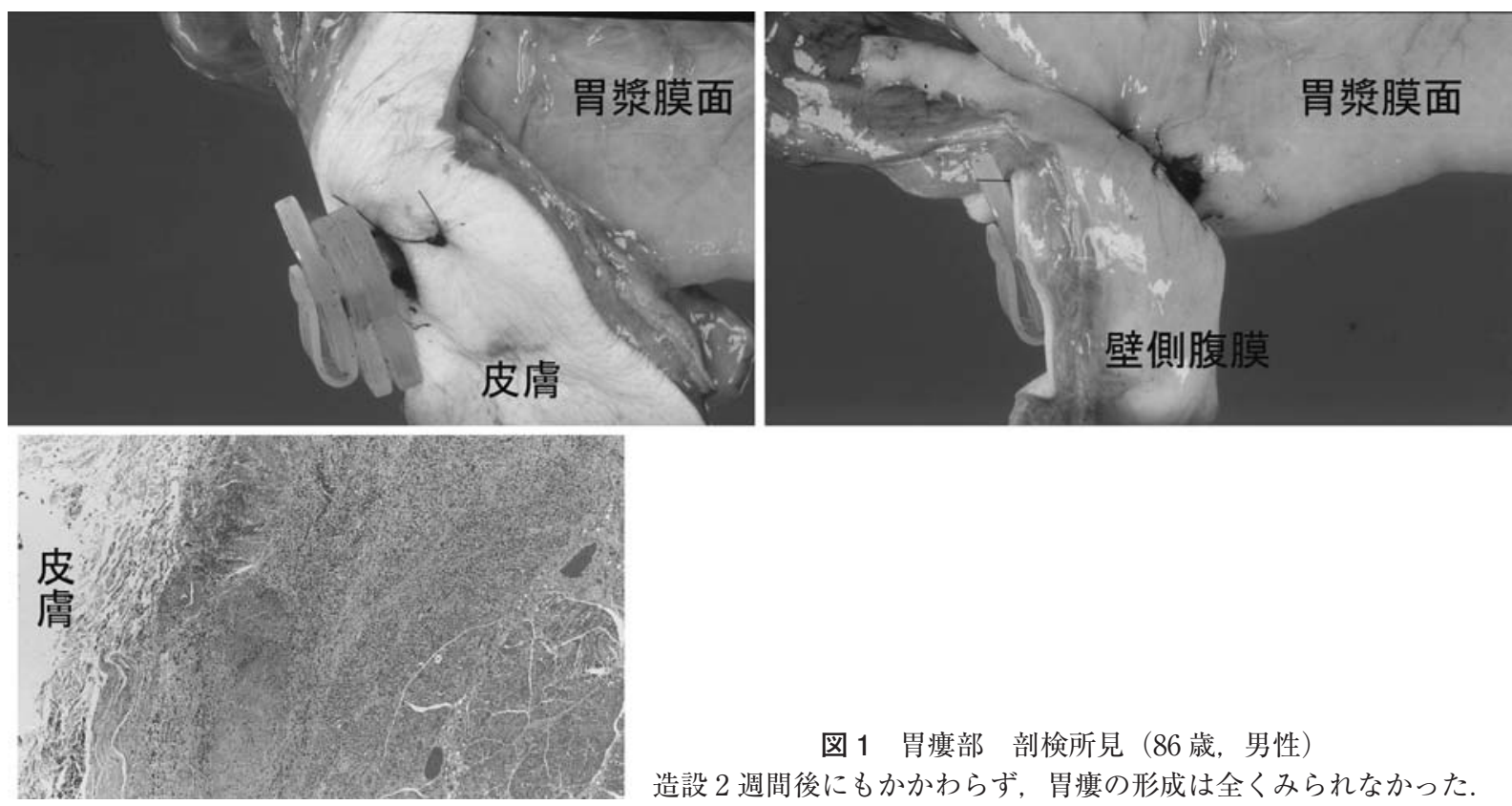

図 1 胃瘦部 剖検所見（86 歳，男性）

造設 2 週間後にもかかわらず，胃瘦の形成は全くみられなかった.

表 1 胃瘻カテーテル各種類の特徵

\begin{tabular}{|c|c|c|}
\hline & バンパー型 & バルーン型 \\
\hline 交換 & やや難しい & しやすい \\
\hline $\begin{array}{l}\text { 耐久性 } \\
\text { 交換時期 }\end{array}$ & $\begin{array}{c}\text { あり } \\
4 \sim 6 \text { カ月 }\end{array}$ & $\begin{array}{c}\text { 弱い } \\
1 \sim 2 \text { 力月 }\end{array}$ \\
\hline $\begin{array}{l}\text { 事故抜去 } \\
\text { (自己·自然) }\end{array}$ & おこりにくい & おこりやすい \\
\hline 管理 & $\begin{array}{l}\text { バルーン水の } \\
\text { 手入れが不要 }\end{array}$ & $\begin{array}{c}\text { バルーン水の } \\
\text { 交換が必要 }\end{array}$ \\
\hline
\end{tabular}

の PEG は絶対に控えるべきである.

\section{胃瘻カテーテル交換時の合併症}

集計した胃㾇交換症例は 155 例, のべ交換回数 461 回 であった，患者背景では造設と同様に女性が多く，平均 年齢は 81.7 歳, 基礎疾患は脳血管障害後遺症が 8 割以 上を占めていた．交換時の内視鏡補助は 148 例 $(32 \%)$, 透視補助は 60 例 $(13 \%)$ で, 交換後に推奨されている 瘦孔造影 8 - 10) を行ったものは 69 例（15\%）に過ぎなかっ た. なお胃内容物の逆流確認や胃泡音の聴取は非常に大 事な事柄と考えられるが，今回集計をとるのは困難で あった。

胃瘻カテーテルの種類を調べると, 交換前はバンパー 型が $37 \%$ ，バルーン型が $62 \%$ であった．交換後にはバ ンパー型が $26 \%$ ，バルーン型が $74 \%$ となり，バルーン 型が好まれる傾向にあった，交換に至る理由は，予定さ れた定期的なものが 7 割を占めていたが, 残りの 3 割は 胃瘦の不具合, 事故抜去 (自然・自己抜去の総称) といっ た，予定外の交換であった。この比較的緊急性のある予
定外交換はバルーン型の症例が多く, 胃瘻の不具合の ケースで $92 \%$, 事故抜去のケースで $74 \%$ を占めていた.

胃瘻交換時の合併症は合計 14 例 $(3 \%)$ に認め, その 内訳は, 誤扦入, 出血, 食道粘膜損傷, 再挿入困難など であった.この 14 例中 10 例はバンパー型の胃㾞を抜去 し交換する際に発生したもので, 胃瘻交換時の合併症の 発生率はバルーン型を交換する時 $(1.3 \%)$ よりバンパー 型を交換する時 $(5.9 \%)$ のほうが有意に高率であった $\left(\chi^{2}\right.$ 検定, $\left.\mathrm{p}<0.05\right)$. バンパー型の抜去時には㾇孔への ストレス負荷が大きく, 愛護的な交換手技が必要である と考えられる.

誤扦入が 461 回の手技で 2 回発生していた $(0.4 \%)$. このうちの 1 例は PEG 後 3 週間目に, 㾇孔拡張目的で カテーテル交換を行った際の誤挿入であった。挿入がス ムースで胃壁固定がされていたことから，胃泡音聴取な どの確認作業がとられていなかった． 2 日後に発熱のた め, 初めて誤扦入が疑われ, 胃㿉造影で判明した。 もう 1 例は造設後 9 カ月の初回交換時のものであった. 直後 に誤挿入に気付き, ガイドワイヤーを腹壁側から操作し, ガイドワイヤーが胃内に再挿入できたことを内視鏡観察 下で確認, 新しいバルーン型カテーテルをガイドワイ ヤーに沿わせて再挿入した。 これら 2 例は初回の交換時 に起こっていることから, 胃瘻造設後初めての交換時に は, 胃瘦組織が不安定と考え, 特に慎重な交換手技が必 要である ${ }^{11) ~ 13)}$.

その他の合併症である食道粘膜損傷は, 内視鏡を用い た交換時に，切断したチューブの断端が食道一胃接合部 

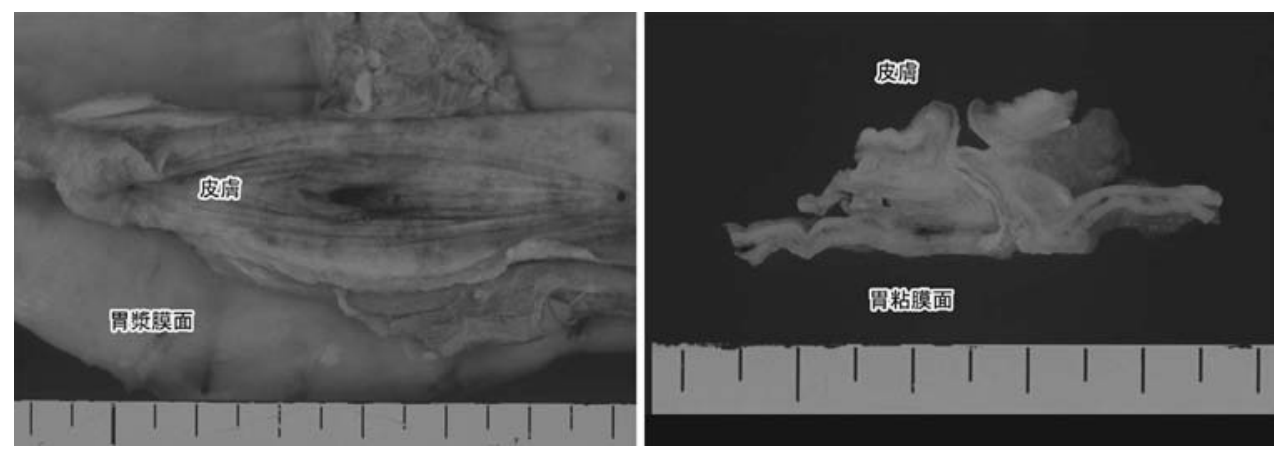

図 2 造設後 3 年の胃瘻所見 (97 歳, 男性) 胃瘻は白く線維化した組織として観察される.
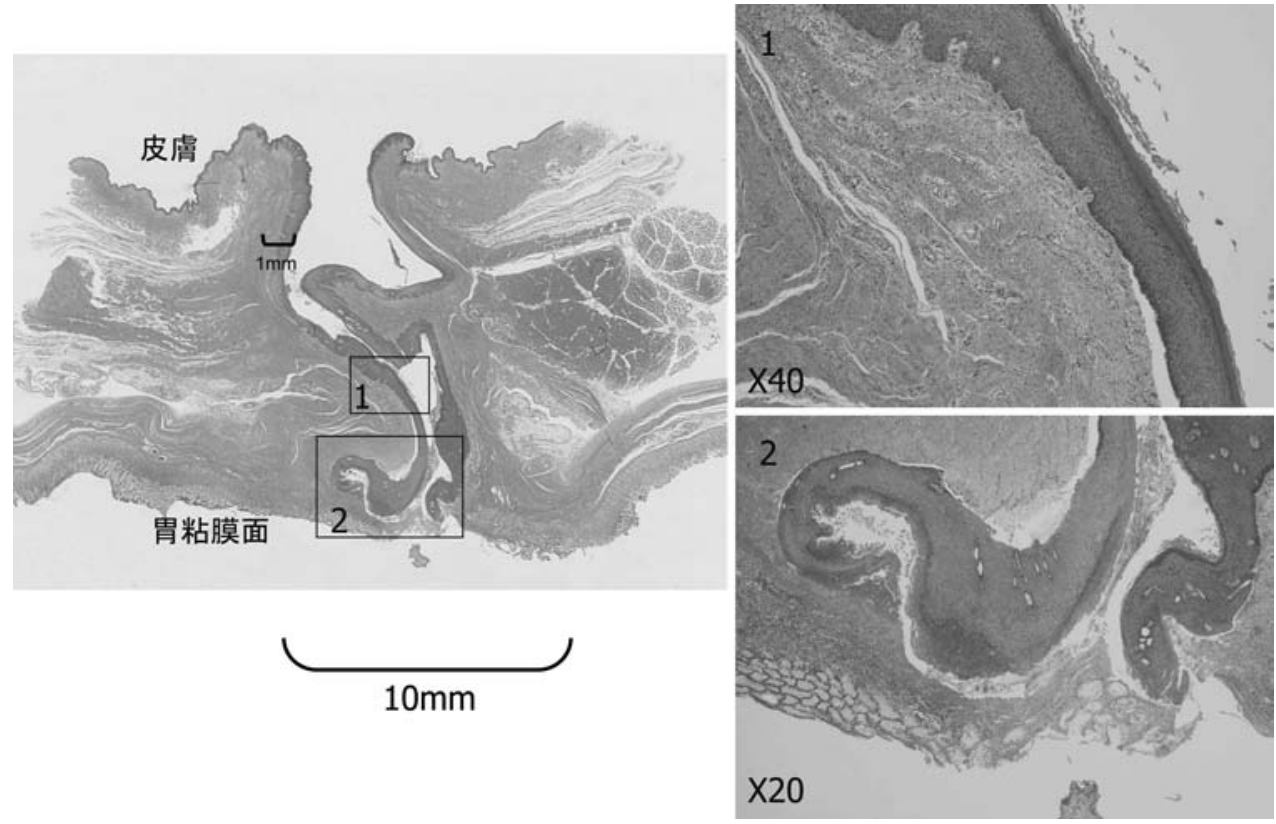

図 3 胃瘻組織所見

瘦孔壁は皮膚表面から胃の粘膜筋板まで連続性に重層扁平上皮で覆われていた。その外側は膠原線維 からなり，胃瘦全体の厚さは 1 〜 $\mathrm{mm}$ 程度であった.

の粘膜を傷つけるものである，内視鏡下での交換は一般 的に安全と考えられているが，このように特有な合併症 も存在する。この損傷を軽減するために，胃内のチュー ブを少し長めに切断し，切り離したチューブを内視鏡と 近接させず，食道の長軸に合わせてゆっくりと内視鏡を 抜去する，といった工夫が考えられる.

最近ガイドワイヤー誘導式の胃瘻交換カテーテルが市 販された. バンパー・ボタン型の胃瘦で, バンパーをオ ブチュレーターで引き伸ばすことができ，付属のガイド ワイヤーの誘導によってカテーテルを胃内に確実に誘導 できる，抜去時も簡便である，実際に交換を行うと，古 いカテーテルを抜いた後にもガイドワイヤーが瘦孔を保 持しているために，非常に安心感がある．挿入時の抵抗 も他のバンパー型に比べかなり少ない. バルーン式の交
換時，在宅における交換時にも役立てることができる.

バンパー型カテーテルとバルーン型カテーテルの比較 を表 1 に示す。一般的に交換はバンパー型がやや難しい とされている.今回の集計でもバンパー型での合併症発 生率が 4 倍以上と有意に高く，これを裏付ける結果で あった。事故抜去はバルーン型のほうに 3 倍多く起こっ ていた.この点ガイドワイヤー誘導式の胃瘻交換はバン パー型にもかかわらず，交換も容易で，欠点が少ない安 全で低侵襲な方法といえる。

最後に胃㾇の組織の検討を追加する。胃㾇造設後 3 年 の経過で肺炎のため死亡した症例（97 歳, 男性）であ る. 肉眼所見で胃㾇は白く線維化した組織として観察さ れ，腹壁と胃壁の癒着は瘻孔部分にのみ認めた（困 2). 顕微鏡所見では，瘦孔壁が皮膚表面から胃の粘膜筋板に 
かけて, 連続性に重層扁平上皮で覆われているのが観察 できた，その外側は膠原線維からなっており，胃瘦全体 の厚さは 1 2mm 程度であった（図 3)。交換時にはわ ずか厚さ 1 2mm の筒に, 硬いオブチュレーターやカ テーテルなどを盲目的に挿入していることになる。これ は造設後 3 年経過した組織像であり, 造設直後の胃㾇は さらに薄く脆弱であることが予想される．挿入方向を確 認しながらの慎重な交換手技が要求される.

\section{おわりに}

胃㿉造設時の合併症について述べたが，その安全性は ほほ確立されていると考えられる，ただしその手術適応 には慎重な検討が要求される。また胃壁固定は造設時の 安全には役立つと考えられるが, 完成後の強固な癒着に は関与していない可能性がある。

交換については症例数の増加とともに, 粗雑で不注意 な交換手技によるアクシデントの増加が懸念される．慎 重な手技，ガイドワイヤーの併用，内視鏡下交換での工 夫などで合併症を防いでいく必要がある．何よりも常に 「瘦孔自体が薄く脆弱な組織から成り立っており, 誰も が誤挿入を起こす危険性があること」を念頭に置くべき である，さらに，交換直後の胃内容物逆流確認，胃泡音 聴取などの確認作業を意らないことも重要である．たと え誤挿入を起こしても，栄養剤を注入する前に気づいて 迅速に対応すれば，重大なアクシデントに発展しないと 考えられる.

名古屋市厚生院の医師を対象にしたアンケートでは, 「将来自分が脳血管障害で燕下障害に陥った場合 PEG を 望まない」という回答が $73 \%$ あった，高齢者医療に携 わる医師は，本音では PEG に否定的であることがうか がわれる．またいたずらに延命効果を求め苦痛を与える ことを疑問視する報告も多( ${ }^{14) \sim 16)}$ ．しかし現実には，消 化器科医への PEG 依頼が減ることはなく，造設件数は 年々増加の一途である。ささらに, PEG 患者の生命予後 が良くなり，交換件数も増加している。これに伴い，実 際にPEG を行った医師以外の医療従事者が交換に携わ る機会も増えていくと考えられる. 胃瘦の理想としては, 100\% 安全で誰でも管理できることが望ましいが，今の ところ残念ながら絶対に安全な交換方法はない，そこで 胃瘦カテーテル交換に打いては，まず事前に適切な交換 方法とカテーテルの種類を選択し，次に交換時の丁寧で 慎重な手技を心がけ，交換後には必ずカテーテルが胃内 に正しく留置されたことを確認することが肝要となる。
今後の PEG の安全な管理を切に望むものである.

\section{文献}

1）嶋尾 仁：内視鏡的胃瘦造設術の現況. Gastroenterol Endosc 2003; 45: 1217-1223.

2）大野眞朋, 河出昌也, 水野弥一, 菊地基雄, 南條邦夫, 稲垣俊明：身体拘束廃止に向けての取り組み一胃瘦造設 の有用性についての検討. 名古屋市厚生院紀要 2005; 31: $9-12$.

3）柴田早苗, 山本 力, 吉岡篤史, 藤井俊光, 堀内亮郎, 田尻和男ほか：経皮内視鏡的胃瘦造設術における早期合 併症減少のための胃壁固定併用の有効性とコストを抑え る工夫. Gastroenterol Endosc 2005; 47: 2146-2151.

4) Thornton FJ, Fotheringham T, Haslam PJ, McGraph FP, Keeling F, Lee MJ: Percutaneous Radiologic Gastrostomy With and Without T-Fastener Gastropexy: A Randomized Comparison Study. Cardiovasc Intervent Radiol 2002; 25: 467-471.

5）石田千穂, 中島 孝, 林 恒美, 遠藤 稔, 福原信義： 長期栄養管理を要する神経疾患患者における胃瘦造設の 有効性と合併症の検討. 神経治療学 1999; 16: 653-657.

6）蟹江治郎：内視鏡的胃瘦造設術における術後合併症の検 討一胃瘦造設 10 年の施行症例より一. Gastroenterol Endosc 2003; 45: 1267-1272.

7) Kanie J, Kono K, Kono T, Osawa M, Yamamoto T, Akatsu H, et al: Complication of percutaneous endoscopic gastrostomy in the elderly: local skin infection and respiratory infection. Nippon Ronen Igakkai Zasshi 2000; 37 (2): 143-148.

8）佐竹信祐, 伊舎堂用大, 村瀬雅美, 里中和廣 : Percutaneous Endoscopic Gastrostomy（PEG）の合併症の検討. Gastroenterol Endosc 2002; 44: 857-863.

9) Platt MS, Roe DC: Complications following insertion and replacement of percutaneous endoscopic gastrostomy (PEG) tubes. J Forensic Sci 2000; 45: 833-835.

10) Garderer MWL: Gastrosomy techniques and devices. Surg Clin North Am 1992; 72: 1285-1298.

11) Fox VL, Abel SD, Malas S, Duggan C, Leichtner AM: Complications following percutaneous endoscopic gastrostomy and subsequent catheter replacement in children and young adults. Gastro intest Endosc 1997; 45: 64-71.

12) Mago H, Chen CL, Wesson DE, Filler RM: Incisionless gastrostomy for nutritional support. J Pediatr Gastroenterol Nutr 1986; 5: 66-69.

13) Romero R, Martinez FL, Robinson SY, Sullivan KM, Hart $\mathrm{MH}$ : Complicated percutaneous endoscopic gastrostomy to skin-level gastrostomy conversions: analysis of risk factors (abstract). J Pediatr Gastroenterol Nutr 1995; 21: 362 .

14) Finucane TE, Christmas $C$, Travis $K$ : Tube feeding in patients with advanced dementia: a review of the evidence. JAMA 1999; 282 (14): 1365-1370.

15）大西丈二, 益田雄一郎, 暮谷雅文, 市川正章, 橋爪眞言, 井口昭久: 総合病院に打ける経皮内視鏡的胃瘦造設術 (PEG) 患者の長期予後と満足感調査. 日本老年医学会 雑誌 2002; 39: 639-642.

16） 大類 孝, 山谷睦雄, 荒井啓行, 佐々木英忠 : 高齢者の 誤噮性肺炎. 日本老年医学会雑誌 2003; 40: 305-313. 